Bond University

Research Repository

\title{
The impact of terrorism on global equity market integration
}

Bilson, Chris; Brailsford, Tim; Hallett, Aiden; Shi, Jing

Published in:

Australian Journal of Management

DOI:

$10.1177 / 0312896211423556$

Licence:

Other

Link to output in Bond University research repository.

Recommended citation(APA):

Bilson, C., Brailsford, T., Hallett, A., \& Shi, J. (2012). The impact of terrorism on global equity market integration. Australian Journal of Management, 37(1), 47-60. https://doi.org/10.1177/0312896211423556

\section{General rights}

Copyright and moral rights for the publications made accessible in the public portal are retained by the authors and/or other copyright owners and it is a condition of accessing publications that users recognise and abide by the legal requirements associated with these rights.

For more information, or if you believe that this document breaches copyright, please contact the Bond University research repository coordinator. 
C. BILSON*

T. BRAILSFORD**

A. HALLETT***

J. SHI*

\title{
THE IMPACT OF TERRORISM ON GLOBAL EQUITY MARKET INTEGRATION
}

\begin{abstract}
In this paper we investigate the short-term contagion and long-term integration effects of terrorist activity on national stock markets. Using the partially-integrated model of Bekaert, Harvey and $\mathrm{Ng}$ (2005), we examine whether changes in cross-border relationships surrounding recent terrorist events are caused by changes in exposure to common risk factors and investigate whether these findings are similar across both developed and emerging market securities. Our research concludes that terrorism induces substantial contagion and market integration effects on national equity markets. Specifically, we provide strong evidence that major terrorist attacks induce substantial contagion consequences, particularly for developed nation equity markets. In terms of longer-term integration effects, a strong increase in cross-market correlation is observed from the pre to post-9/11 period. However, we find little evidence of an increase in the risk exposures of national markets to common risk factors, suggesting that this heightened correlation is driven by an increase in global risk factor uncertainty. This finding is consistent with the argument that an increase in the risk-aversion of market participants is associated with terrorist attacks.
\end{abstract}

JEL Codes: F37, G15

Key words: Terrorism, Contagion, Capital Market Integration, International equity markets

* School of Finance and Applied Statistics, Australian National University, Australia

** UQ Business School, The University of Queensland, Australia

*** Merrill Lynch, Sydney, Australia. 


\section{INTRODUCTION}

Since the September 112001 terrorist attacks (9/11), the impact of terrorist events on financial markets has become heightened. However, the mechanism by which these events propagate across markets is not widely understood. Prior research on markets affected by terrorist activity has documented increased financial market volatility and abnormally low returns in the period immediately following attacks. Interestingly, so-called 'contagion' effects have been documented in markets not directly impacted by the terrorist attack, whereby return and volatility impacts are observed (Chen and Seims, 2005). However, despite the influence and media focus on terrorist activity, research in this area has been relatively limited. Further, existing research has predominantly focused on the short-term, or contagion impacts, and typically limits its analysis to measuring the impact of the 9/11 event on industrial capital markets.

Consequently, this study expands research in this area in three ways. First, we adopt the riskbased methodology of Bekaert, Harvey and Ng (2005), which is explicitly set within a partially-integrated asset pricing framework. This methodology permits an analysis of the effects of terrorism on both short-term and long-term equity market linkages, and perhaps most importantly on the risk-profiles of the affected markets. This approach is in contrast to much of the previous literature in the area which focuses on the traditional event study methodology (for example Ramiah et al., 2010 and Chesney et al, 2011). Second, we expand the focus of the previous research beyond 9/11 to consider the impact of other major recent terrorist attacks. Finally, the study examines both developed and emerging markets to distinguish between the implications for markets with varying degrees of integration. This final contribution permits us to investigate potential asymmetry in capital flows around terrorist events between countries with varying capital market development.

To achieve these objectives, we derive a contemporaneous event sample of recent major terrorist attacks and examine the related effects on a comprehensive national equity market sample of 45 markets; comprising 21 developed and 24 emerging nation equity markets. Overall, our research concludes that terrorism induces substantial contagion and market integration effects on national equity markets. Specifically, the strongest contagion effects 
are observed for developed markets surrounding the 9/11 event. In terms of longer-term integration effects, a strong increase in cross-market correlation is observed from the pre to post-9/11 period. However, we find little evidence of an increase in the risk exposures of national markets to global or regional risk factors, suggesting that this heightened correlation is driven by an increase in global risk premia. This finding is consistent with previous research suggesting that terrorist activity may result in an increase in the risk-aversion of market participants.

The remainder of the paper initially proceeds by providing a review of the relevant literature in Section Two. Section Three details the methodology, while Section Four outlines the sample. Section Five reports the primary results of the investigation. Finally, Section Six draws conclusions from the analysis.

\section{PRIOR STUDIES}

As with other system shocks, it is expected that financial markets within the country targeted by the terrorist attack will be affected to some degree. By definition, such attacks are unexpected and hence market prices should react to the information as news. However, whether these shocks are transmitted to the financial markets of other countries is less obvious (Kodres and Pritsker, 2002). Under the assumption of capital market integration and equality in relation to real rates of return, investors will trade securities internationally such that the expected return on similar risk securities should be equalised (Adler and Dumas, 1983). Even under mild assumptions of integration (such as those proposed by Errunza and Losq, 1985), cross-border market linkages arise due to macroeconomic similarities (Karolyi and Stulz, 1996; Bracker, Doching and Koch, 1999; and, Hernandez and Valdez, 2001); trade linkages (Eichengreen, Rose, Wyplosz, 1996; Glick and Rose, 1999; Dornbusch, Park and Claessens, 2000); and/or, financial linkages (Bekaert and Harvey, 1995 and Phylaktis and Ravazzolo, 2002). Further, even where economic linkages are weak between nations, informational asymmetries between market participants can result in portfolio rebalancing of global portfolios and subsequent cross-hedging of national idiosyncratic risks (Kodres and Pritsker, 2002 and Karolyi, 2003). It is these direct macroeconomic linkages, and/or indirect 
informational asymmetries, that drive the longer-term integration of national capital markets, and that provide a mechanism for transitory contagion to occur (Ferreira and Laux, 2008).

In general, 'contagion' refers to the short-term propagation of financial market shocks from one country to another and can be observed via co-movements in security price changes (Karolyi, 2003; and, Moser, 2003). However, the extant literature provides numerous definitions and measures of financial market contagion (Forbes and Rigobon, 2002). For example, King and Wadwhani (1990) propose increased correlation between markets following a major shock occurs as a result of market participants inferring information from price changes in other countries. Forbes and Rigobon (2002) argue that a shock resulting in a distinct increase in the extent of cross-market linkage over and above that previously existing represents the effect of contagion. Similarly, Bekaert, Harvey and Ng (2005) define contagion not only as an increase in cross-market correlation, but more specifically as an increase in excess of that expected based on economic fundamentals.

While limited empirical evidence investigating the contagion impacts of terrorism currently exists (see, for example Hon, Strauss and Yong, 2004; and, Mun, 2005), a substantial body of literature documents significant contagion effects following financial crises (see, for example, King and Wadwhani, 1990; and, Calvo and Reinhart, 1996), and catastrophic events (see, for example, Fields and Janjigian, 1989; and, Kalra, Henderson and Raines, 1993). These effects have been associated with capital flight towards safety assets (Johnston and Nedelescu, 2005). For this reason, unexpected increases in uncertainty following major terrorist attacks should result in abnormal returns on a broad scale (see, for example, Drakos, 2004; Glaser and Weber, 2005; and, Fernandez, 2006). Indeed, the extant literature documents evidence of substantial returns, volatility and contagion effects on financial markets as a result of acts of terrorism. Carter and Simkins (2002) report negative abnormal returns across the US airline industry stocks following the 9/11 terrorist attacks. Furthermore, Drakos (2004) finds significant increases in systematic and idiosyncratic risk associated with airline equity markets in the post-9/11 environment. Chen and Siems (2004) investigate the US equity market response to terrorist attacks between 1915 and 2001, consistently finding a negative market response in each instance of terrorism. Moreover, Chen and Siems (2004) 
conduct a detailed examination of the response of 29 national equity markets to the $9 / 11$ terrorist attacks and find strong evidence of significant global negative abnormal returns. While Glaser and Weber (2005) confirm that market participants perceive the post-9/11 environment to be comparatively more risky than prior to the event. Finally, following the 9/11 terrorist attacks, Mun (2005) documents evidence of significant volatility contagion from the USA to the United Kingdom and Germany; and significant return contagion from the USA to Japan.

\section{CONTAGION MODELS}

King and Wadhwani (1990); and Solnik, Boucrelle and Le Fur (1996) advocate the use of simple return correlation to measure cross-border return linkages. Specifically, for any market pair, the raw cross-market correlation $\left(\rho_{i, j}\right)$ over a particular event window $[\mathrm{t}, \mathrm{T}]$ can be defined as:

$$
\rho_{t, T}^{i, j}=\frac{\sigma_{t, T}^{i, j}}{\sigma_{t, T}^{i} \cdot \sigma_{t, T}^{j}}
$$

where,

$$
\begin{array}{ll}
\sigma^{i, j}{ }_{t, T}= & \begin{array}{l}
\text { the covariance between national equity market } i \text { and national } \\
\text { equity market } j \text { during the event window }[\mathrm{t}, \mathrm{T}],
\end{array} \\
\sigma^{i j}{ }_{t, T}= & \begin{array}{l}
\text { the standard deviation of national equity market } i \text { during the event } \\
\text { window }[\mathrm{t}, \mathrm{T}] \text { and }
\end{array} \\
\sigma_{t, T}^{j}= & \begin{array}{l}
\text { the standard deviation of national equity market } j \text { during the event } \\
\text { window }[\mathrm{t}, \mathrm{T}] .
\end{array}
\end{array}
$$

While seemingly crude, the advantage of the correlation metric is that it is free of assumptions regarding the factor structure of international returns. As such it avoids the much publicised difficulty in defining systematic risk in the international context (Bekaert and Harvey, 1995; and Heston, Rouwenhorst and Wessels, 2005) and as a consequence avoids the issue of omitted variable bias. ${ }^{1}$ However, the correlation measure has been shown

\footnotetext{
${ }^{1}$ Brennan, Chordia and Subrahmanyam (1998) discuss this issue in the context of asset pricing models, while Rigabon (2003) shows how omitted variables can impact on measures of cross-market linkages.
} 
to be influenced by changes in market volatility. Specifically, Forbes and Rigobon (2002) show that increased market volatility may result in a spurious increase in association, despite no change in the underlying linkage between the market returns.

With the above limitation in mind, we also estimate cross-market linkages using the factor model of Bekaert, Harvey and $\mathrm{Ng}$ (2005). This model (hereafter referred to as the BHNmodel) assumes that markets are integrated either internationally or regionally, and is expressed as;

$$
R_{i, t}=\beta_{0}+\beta_{i, w} R_{w, t}+\beta_{i, \text { reg }} R_{r e g, t}+\varepsilon_{i, t}
$$

Where:

$$
\begin{array}{lll}
R_{i, t} & = & \text { The return on national equity market } i \text { at time } \mathrm{t} ; \\
R_{w l d, t} & = & \text { The return on the world market index at time } \mathrm{t} ; \\
R_{\text {reg,t }} & = & \text { The return on regional equity market index, at time } \mathrm{t} ; \\
\varepsilon_{i, \mathrm{t}} & = & \text { The residual term for country } i \text { at time } \mathrm{t} .
\end{array}
$$

The first factor in the BHN model $\left(R_{w l d, t}\right)$ is the world market factor from the International CAPM of Solnik (1976) and Adler and Dumas (1983). Under the assumption of global market integration, expected returns should be a linear function of the excess return on the world market. Harvey (1991) finds evidence to support the pricing of this factor for a set of 21 developed markets, but found that this conclusion fails to hold for an emerging market sample (Harvey, 1995). The second factor $\left(\mathbf{R}_{\text {reg,t }}\right)$ is a regional factor, calculated as the equity market return on a portfolio of geographically proximate nations. This factor has its origins in the convergence literature of economics (Romer, 1986; Lucas, 1988), whereby production factors (in particular labour) are assumed to be more highly mobile within a region than without. Under this assumption, factor costs and income growth are equalised on a regional basis, with the resultant economic integration being a precursor to greater regional financial integration (Phylaktis and Ravazzolo, 2002). In support of such a regional effect, Bekaert, Harvey and $\mathrm{Ng}$ (2005) find consistently strong exposure to such a regional factor. Similarly, Cheung, He and $\mathrm{Ng}$ (1997) find regional similarities in the factors predicting excess stock returns on national market indices. 
While the evidence primarily supports a significant degree of market integration, contradictory evidence is also present, therefore indicating that findings are mixed. The current state of extant market integration literature tends to suggest markets experience a degree of integration that is partially characteristic of the integration continuum extremities of full segmentation and full integration (Choi and Rajan, 1997). Further, these integration levels have been shown to demonstrate significant time variation (Bekaert and Harvey, 1995; Bekaert, Harvey and $\mathrm{Ng}$, 2005). Notwithstanding these issues, the two factor BHN model is not susceptible to the volatility induced bias of the correlation measure. Further, it permits us to identify the source of any change in market linkages. Specifically, any change in the global or regional integration levels of the markets would be observed through the $\beta_{i, w l d}$ or $\beta_{i, \text { reg }}$ coefficients, respectively, or through the idiosyncratic (ie. market specific) term $\left(\varepsilon_{i, t}\right)$ being more highly correlated across markets. ${ }^{2}$

\section{SAMPLE}

To examine the contagion and integration effects of terrorism, we construct a sample of 'significant' terrorist attacks, from the Terrorist Research Centre's Terrorist Attacks Database. The US Department of State defines a 'significant' terrorist attack as terrorist attacks that kill, or seriously injure, at least 10 individuals and cause more than $\$ 10,000$ in damage. ${ }^{3}$ The final sample is obtained by adding the additional filter according to the following criteria. First, we focus on the most recent attacks, which have occurred over the 1996-2006 period. Second, we restrict our sample to consider prominent terrorist attacks. Specifically the attacks must be against a developed market, cause significant damage and receive a high level of media coverage. ${ }^{4}$ Based on this filtering process we obtain a final sample of six major terrorist attacks during the period 1998 to 2005. The attacks that comprise the final sample include:- US Embassy bombings in East Africa (7th August, 1998); USS Cole attack in Yemen (12th October, 2000); September 11 attacks in the USA (11th September, 2001);

\footnotetext{
${ }^{2}$ This issue is discussed in length in Section V.

${ }^{3}$ This information is available on the US Department of State's website (http://www.state.gov/).

${ }^{4}$ These requirements increase the likelihood of consequences from the terrorist attacks. Further, we require each event to be the subject of global media coverage generating greater than 500 related press articles in the three months following the initial attack, which is identified through Factiva. We search titles and lead paragraphs of all press channels for key words identifying each terrorist attack using Factiva.
} 
Bali bombings in Indonesia (12th October, 2002); Madrid bombings in Spain (11th March, 2004); and the London Bombings in the UK (7th July, 2005).

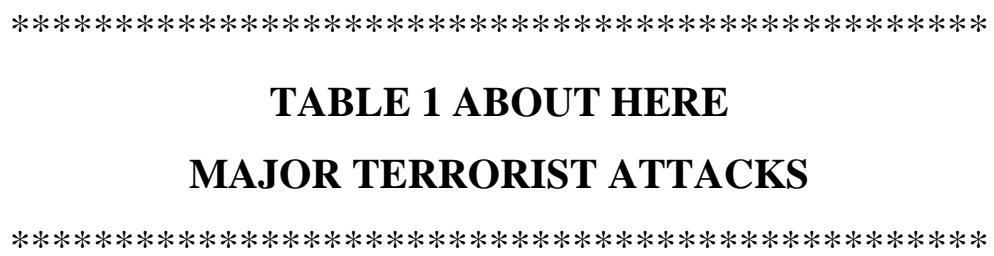

Initially, we report key information associated with each terrorist attack comprising our final event sample in Table I. Inspection of Table I identifies the most severe consequences of all event sample attacks are attributable to 9/11. Further, the least recent terrorist attack we investigate is the US Embassy bombings on 07-Aug-1998; while the most recent attack we examine is the London bombings on 07-Jul-2005.

We investigate the contagion and market integration impact of terrorism at the national level. To accomplish this, we collect daily return data for 45 national equity markets, comprising 21 developed nations and 24 emerging nations. ${ }^{5}$ Consistent with the extant literature, we utilise the MSCI World Equity Market Index as our proxy for world equity market returns (see, Bekaert and Harvey, 1995). All returns are continuously compounded, include dividends and capitalisation adjustments and are converted to a common numeraire (in this case the US dollar) using prevailing daily spot rates. Regional indices are constructed for each country by value-weighting the index returns of geographically neighbouring countries, excluding the return for that particular country.

$* * * * * * * * * * * * * * * * * * * * * * * * * * * * * * * * * * * * * * * * * * * * * * * *$

TABLE 1I - PANEL A ABOUT HERE DESCRIPTIVE STATISTICS: DEVELOPED MARKET SAMPLE

$* * * * * * * * * * * * * * * * * * * * * * * * * * * * * * * * * * * * * * * * * * * * * * *$

$* * * * * * * * * * * * * * * * * * * * * * * * * * * * * * * * * * * * * * * * * * * * * * *$

\footnotetext{
${ }^{5}$ This sample is consistent with other studies of national indices (eg. Harvey, 1991 and 1995).
} 


\section{TABLE 1I - PANEL B ABOUT HERE DESCRIPTIVE STATISTICS: EMERGING MARKET SAMPLE}

$* * * * * * * * * * * * * * * * * * * * * * * * * * * * * * * * * * * * * * * * * * * * * * *$

Panels A and B of Table II detail market capitalisation characteristics pertaining to the 45 national equity markets. In aggregate, the national equity market sample represents a total market capitalisation of US $\$ 22,527,082$ million. The US equity market accounts for the largest proportion of the total sample market capitalisation $(49.55 \%)$ and is followed by Japan $(11.02 \%)$ and the UK $(9.21 \%)$. Furthermore, the total developed nation equity market capitalisation embodies $95 \%$ of the total sample capitalisation with the remaining emerging market nations attributable to only $5 \%$ of the total. Of the emerging nation markets Taiwan, Korea and Brazil are the largest national emerging equity markets in our sample, representing $16.22 \%, 14.38 \%$ and $12.62 \%$ of the total emerging market sample's market capitalisation.

Analysis of the Jarque-Bera statistics reveals evidence that all daily return series are significantly non-normally distributed. This observation is consistent with existing literature that finds daily return series are generally characterised as exhibiting skewness and excess kurtosis. Using Augmented Dickey-Fuller tests, we find no evidence of non-stationarity in the return series for any of the countries in our sample.

\section{ANALYSIS AND RESULTS}

As a precursor to the formal tests, we examine cross-market correlations around the major terrorist events. This enables us to obtain an overview of the market reactions surrounding terrorist events. To accomplish this, we calculate 12-month rolling correlations of each market's returns with the world market index return. Using an equally-weighted approach, we aggregate these country correlations for each of (1) the developed markets sample; (2) the emerging markets sample and (3) the combined developed and emerging markets sample. ${ }^{6}$ These correlations are depicted in Figure I. Consistent with the current literature (see, for example, Bekaert, 1995) we observe a persistently higher level of world market integration for the developed nation equity markets in comparison to the emerging nation equity

\footnotetext{
${ }^{6}$ Value-weighted analysis is conducted at a later stage of the paper.
} 
markets. Furthermore, the figure is generally suggestive of the notion that cross-market correlations rise following terrorist activity.

\section{$* * * * * * * * * * * * * * * * * * * * * * * * * * * * * * * * * * * * * * * * * * * * * * *$ \\ FIGURE I ABOUT HERE CORRELATIONS AROUND ATTACKS \\ $* * * * * * * * * * * * * * * * * * * * * * * * * * * * * * * * * * * * * * * * * * * * * * * *$}

Table III presents a more precise statistical inspection of the contagion impacts of terrorist attacks. We define contagion as raw cross-market correlations, as advocated by King and Wadwhani (1990). To accomplish this, we initially compare the cross-market correlations between national equity markets before the terrorist attacks with their respective correlations after the attack. Following Chen and Siems (2002) we use a one-month estimation window to calculate the cross-market correlations. ${ }^{7}$ To address potential heteroskedasticity and autocorrelation bias emphasised by Forbes and Rigobon (2002), standard errors are calculated using the heteroskedasticity and autocorrelation consistent standard error method prescribed by Newey and West (1987). ${ }^{8}$ These results are reported in Panel A of Table III.

The second method used to examine contagion is through the analysis of the residuals from the BHN model, as in equation (2). These results are reported in Panel B of Table III.

$* * * * * * * * * * * * * * * * * * * * * * * * * * * * * * * * * * * * * * * * * * * * * * * *$

TABLE III

CONTAGION EFFECTS

$* * * * * * * * * * * * * * * * * * * * * * * * * * * * * * * * * * * * * * * * * * * * * * * *$

To understand the figures in Table III, recognise that the table reports the average of the changes in raw correlations (Panel A) and factor model residuals (Panel B) for each of the six

\footnotetext{
${ }^{7}$ Using the event study approach of Brown and Warner (1985), Chen and Siems (2002) show that a one-month window is sufficiently large to capture the majority of the price movement associated with the terrorist attacks in their sample. The analysis was recalculated using both 5-day and 3-month windows without altering our conclusions.

${ }^{8}$ This regression approach is formally presented in the following equation: $\rho_{i j, t}=\beta_{0}+\beta_{1} \operatorname{Attack}_{t}+\varepsilon_{i j, t}$.
} 
terrorist attacks in our sample. Columns (4), (5) and (6) report the value-weighted average of the changes for the group of the 45 markets in the sample, the 24 developed markets and 21 emerging markets, respectively. Consistent with prior literature, we conduct our analysis using value-weightings as we are interested in the impact of terrorist attacks on an international investor's portfolio, rather than on the local equity markets per se. Interestingly, the average results show general consistency between the Panel A and B results, indicating that the findings are robust when we control for changes in economic fundamentals surrounding the event date (Bekaert, Harvey and $\mathrm{Ng}, 2005$ ).

Consistent with Hon, Strauss and Yong (2004) and Mun (2005), we find significant evidence of increases in raw cross-market correlations following these attacks. However, closer inspection reveals that this result is driven by the developed market sample, and the average impact on cross-correlations in the emerging market sample is actually negative. The asymmetric effect is perhaps supportive of the conclusions of Johnstone and Nedelescu, 2005, who argue that such events may result in a flight of capital into safety assets, and away from such assets as emerging market equities. ${ }^{9}$ However, one exception to these general findings is the contagion associated with the 9/11 attacks. In contrast with most of the other events, the 9/11 event was associated with strong positive increases in raw correlations for both developed and emerging markets in the sample. This conclusion is consistent with findings of contagion effects following 9/11 by Hon, Strauss and Yong (2004) and Mun (2005). Furthermore, our findings are also consistent with the broader catastrophic events extant literature that demonstrate substantial evidence of global contagion effects (see, for example, Fields and Janjigian, 1989; and, Kalra, Henderson and Raines, 1993). Such a mechanism could result in more permanent impacts on cross-border linkages, and thereby influence the integration level of national equity markets. As such, we now turn our attention to the longer-term integration impacts of the $9 / 11$ event.

Table IV presents the more permanent effects of terrorism on cross-market correlation than the contagion analysis. Consequently, it provides an insight into the international integration

\footnotetext{
${ }^{9}$ There is extensive literature indicating that emerging market assets are considered risky to international investors, and are associated with heightened volatility, political risk susceptibility and large exchange rate fluctuations (eg. Bekaert and Harvey, 2000).
} 
effects of the terrorism phenomenon. Panel A reports the average aggregated cross-market return correlation changes for selected medium to long-term event windows. Most notably, we observe significant positive cross-market correlation increases in the 3 and 5-year periods in the post-9/11 environment. While this result is evident overall, it appears to be entirely attributable to changes identified in the developed nation market sample, since none of the changes in return correlations in the emerging market sample are significant. This conclusion is largely consistent with the extant literature that indicates substantial fundamental changes in equity market linkages in the post-9/11 environment (see, for example, Glaser and Weber, 2005).

$* * * * * * * * * * * * * * * * * * * * * * * * * * * * * * * * * * * * * * * * * * * * * * * * * *$

TABLE IV

INTEGRATION EFFECTS

$* * * * * * * * * * * * * * * * * * * * * * * * * * * * * * * * * * * * * * * * * * * * * * * * *$

Even though the observed increase in raw correlations observed in Panel A of Table IV looks compelling, the increased correlation is not necessarily associated with greater exposure to global systematic risk factors (Lessard (1973) and Griffin and Karolyi (1998)). As explained by Bekaert, Harvey and Ng (2005), the increased correlation between markets could be due to either increased exposure to common risk factors or to an increase in the volatility of the risk factors themselves. ${ }^{10}$ For example, Forbes and Rigobon (2002) show how changes in the level of volatility have significant impact on the accuracy of raw correlation. Given that our integration tests necessarily involve long estimation windows, the assumption of constant volatility is likely to be violated. Due to these difficulties, we focus instead on the risk exposures. $^{11}$

The investigation of risk exposures in an international context is the central premise of the capital market integration literature. Specifically, heightened cross-market correlations could

\footnotetext{
${ }^{10}$ As discussed earlier, these common factors could be either global or regional in nature.

${ }_{11}$ There is extensive literature on volatility modelling, ranging from autoregressive models (such as the GARCH and ARCH models) to the stochastic volatility representations. These models tend to be less reliable in periods of market turbulence, due to jumps in volatility (Chiang, Jeon and Li, 2007).
} 
be driven by the strengthening of common information linkages at either the global or regional level. Similarly, this would be consistent with a reduction in the importance of localmarket (ie. idiosyncratic) information (Henry, 2000). Panel B of Table IV reports the change in average exposures for the full, developed and emerging market samples to each of the global regional factors, as well as the idiosyncratic correlations. ${ }^{12}$ From the table, we find little evidence to support an increase in correlation. Whilst the change in global betas before and after $9 / 11$ is positive, it is statistically insignificant and the reduction in idiosyncratic risk correlation is only significant for the emerging market sample. This finding is supportive of the conclusions of Goetzmann, $\mathrm{Li}$ and Rouwenhorst (2005) who find little evidence of increased capital market integration over the past 20 years. The one significant result for the developed markets sample is the negative change in regional beta. However, as this result is negative, it is actually supportive of a decrease in cross-market correlation. In light of no evidence supporting an increase in the risk exposures of the markets in our sample, we conclude that it is greater volatility in the global and regional risk factors that is driving the heightened correlations after 9/11. Such an increase in volatility is consistent with the arguments of Glaser and Weber (2005) that the 9/11 attacks resulted in increased expected returns due to an increase in investor risk aversion.

\section{DISCUSSION AND CONCLUSION}

In this paper, the risk-based methodology of Bekaert, Harvey and $\mathrm{Ng}$ (2005) is employed to investigate both short-term and long-term effects of terrorist activity. Second, we expand the focus of the previous research beyond 9/11 to consider the impact of other major recent terrorist attacks. Finally, our methodology allows us to distinguish between the implications for both developed and emerging nation markets. To achieve these objectives, we derive a contemporaneous event sample of recent major terrorist attacks directed towards developed nations and examine the related effects on a comprehensive national equity market sample of 45 markets; comprising 21 developed and 24 emerging nation equity markets.

12 These exposures are estimated using the model of Bekaert, Harvey and $\mathrm{Ng}$ (2005), via $R_{t}=\beta_{0}+\beta_{i, w} R_{w, t}+\beta_{i, \text { reg }} R_{i, \text { reg }}+\varepsilon_{i, t}$. This model is estimated using a 5-year window before $9 / 11$ and 5 -years after $9 / 11$. The table reports the change in coefficients and correlation across these two samples. To address potential heteroskedasticity and autocorrelation bias emphasised by Forbes and Rigobon (2002), standard errors are calculated using the heteroskedasticity and autocorrelation consistent standard error method prescribed by Newey and West (1987), and are calculated using Chow's breakpoint test (Chow (1960). 
Overall, our research concludes that terrorism induces substantial contagion and market integration effects on national equity markets. Specifically, that major terrorist attacks induce substantial contagion consequences, particularly for developed nation equity markets. In particular, we identify that on average terrorist activity results in short-term contagion, even after controlling for economic fundamentals. Importantly, we identify asymmetry between developed and market samples, with emerging market linkages reducing significantly in response to these events. In terms of longer-term integration effects, a strong increase in cross-market correlation is observed from the pre to post-9/11 period. However, we find little evidence of an increase in the risk exposures of national markets to global risk factors, suggesting that this heightened correlation is driven by an increase in the volatility of global risk factors. This finding is consistent with previous authors that have suggested an increase in the risk-aversion of market participants associated with terrorist attacks. 


\section{BIBLIOGRAPHY}

Adler, M. and B. Dumas, 1983, "International Portfolio Choice and Corporation Finance: A Synthesis", Journal of Finance, v38(3), pp925-984.

Bekaert, G., 1995, "Market Integration and Investment Barriers in Emerging Equity Markets", World Bank Economic Review, v9, pp75-107.

Bekaert, G. and C. Harvey, 1995, "Time-Varying World Market Integration”, Journal of Finance, v50(2), pp. 403-444.

Bekaert, G. and C. Harvey, 2000, "Foreign Speculators and Emerging Equity Markets", Journal of Finance, v55, pp565-613.

Bekaert, G., C. Harvey and A. Ng, 2005, "Market Integration and Contagion", Journal of Business, v78(1), pp. 39-69.

Bracker, K., D, Docking and P. Koch, "Economic Determinants of Evolution in International Stock Market Integration", Journal of Empirical Finance, v6, pp1-27.

Brennan, M., T. Chordia and A. Subrahmanyam, 1998, "Alternative Factor Specifications, Security Characteristics, and the Cross-Section of Expected Returns", Journal of Financial Economics, v49, pp345-373.

Brown, S. and J. Warner, 1985, "Using Daily Stock Returns: The Case of Event Studies, Journal of Financial Economics, v14, pp3-31.

Calvo, S. and C. Reinhart, 1996, "Capital Flows to Latin America: Is the Evidence of Contagion Effect?", in Private Capital Flows to Emerging Markets After the Mexican Crisis, Institute for International Economics, Washington D.C.

Carter, D. and B. Simkins, 2002, "Do Markets React Rationally? The Effect of the September 11th Tragedy on Airline Stock Returns", Working Paper, Oklahoma State University.

Chen, A, and T. Siems, 2004, "The Effects of Terrorism on Global Capital Markets", European Journal of Political Economy, v20, pp. 349-366.

Chesney, M., G. Reshetar and M. Karaman, 2011, "The impact of terrorism on financial markets: An empirical study", Journal of Banking and Finance, v35(11), pp253-267.

Cheung, Y-W., J. He and L. Ng, 1997, "Common Predictable Components in Regional Stock Markets", Journal of Business and Economic Statistics, v15(1), pp35-42. 
Chiang, T., B. Joen, and H. Li, 2007, "Dynamic Correlation Analysis of Financial Contagion: Evidence from Asian Markets", Journal of International Money and Finance, v26, pp1206-1228.

Choi, J. and M. Rajan, 1997, "A Joint Test of Market Segmentation and Exchange Risk Factor in International Capital Markets", Journal of International Business Studies, v28(1), pp29-49.

Chow, G., 1960, "Tests of Equality Between Sets of Coefficients in Two Linear Regressions", Econometrica, v28, pp591-605.

Dornbusch, R., Y. Park and S. Claessens, 2000, "Contagion: Understanding How It Spreads", World Bank Research Observer, v15(2), pp. 177-197.

Drakos, K., 2004, “Terrorism-Induced Structural Shifts in Financial Risk: Airline Stocks in the Aftermath of the September 11th Terror Attacks", European Journal of Political Economy, v20, pp435-446.

Eichengreen, B., A. Rose and C. Wyplosz, 1996, "Contagious Currency Crises: First Tests", Scandinavian Journal of Economics, v98(4), pp463-484.

Errunza, V. and E. Losq, 1985, "International Asset Pricing under Mild Segmentation: A Test", Journal of Finance, v40(1), pp105-124.

Fernandez, V., 2006, "The Impact of Major Global Events on Volatility Shifts: Evidence from the Asian Crisis and 9/11”, Economic Systems, v30, pp79-97.

Ferreira, M. and P. Laux, 2008, "Portfolio flows, Volatility and Growth", Journal of International Money and Finance, v28(2), pp271-292.

Fields, A. and V. Janjigian, 1989, "The Effect of Chernobyl on Electric-Utility Stock Prices", Journal of Business Research, v18, pp81-88.

Forbes, K. and R. Rigobon, 2002, "No Contagion, Only Interdependence: Measuring Stock Market Co-movements", Journal of Finance, v57(5), pp. 2223-2261.

Glaser, M. and M. Weber, 2005, "September 11 and Stock Return Expectations of Individual Investors", Review of Finance, v9, pp243 - 279.

Glick, R. and A. Rose, 1999, "Contagion and Trade: Why are Currency Crises Regional?", Journal of International Money and Finance, v18(4), pp. 603-617.

Goetzmann, W., L. Li and G. Rouwenhorst, 2005, "Long-Term Global Market Correlations", Journal of Business, v78(1), pp1-38. 
Griffin, J. and A. Karolyi, 1998, "Another look at the role of the Industrial Structure of markets for International Diversification Strategies", Journal of Financial Economics, v50, pp351-373.

Harvey, C., 1991, "The World Price of Covariance Risk", Journal of Finance, v46, pp111157.

Harvey, C., 1995, "Predictable Risk and Return in Emerging Equity Markets", Review of Financial Studies, v8, p773-816.

Henry, P., 2000, "Stock Market Liberalization, Economic Reform and Emerging Market Equity Prices", Journal of Finance, v55(2), pp529-564.

Hernandez, L. and R. Valdez,2001, "What Drives Contagion: Trade, Neighbourhood or Financial Links", International Review of Financial Analysis, v10, pp. 203-218.

Heston, S. G. Rouwenhorst and R. Wessels, 1995, "The Structure of International Stock Returns and the Integration of Capital Markets", Journal of Empirical Finance, v2, pp173-197.

Hon, M., J. Strauss and S. Yong, 2004, "Contagion in Financial Markets after September 11: Myth or Reality?", Journal of Financial Research, v27(1), pp. 95-114.

Jarque, C. and A. Bera, 1980, "Efficient Tests for Normality, Homoscedasticity and Serial Independence of Regression Residuals, Economics Letters, v6, pp255-259.

Johnston, R. and O. Nedelescu, 2005, "The Impact of Terrorism on Financial Markets", IMF Working Paper, WP/05/60.

Kalra, R., G. Henderson, and G. Raines, 1993, "Effects of the Chernobyl Nuclear Accident on Utility Share Prices", Quarterly Journal of Business and Economics, v32, pp. 5278.

Karolyi, A., 2003, "Does International Financial Contagion Really Exist?", International Finance, v6(2), pp179-199.

Karolyi, A. and R. Stulz, 1996, "Why do stock markets move together? An Investigation of US-Japan Stock Return Commovement", Journal of Finance, v51, pp951-986.

King, M. and S. Wadwhani, 1990, "Transmission of Volatility between Stock Markets", Review of Financial Studies, v3, pp. 5-33.

Kodres, L., and M. Pritsker, 2002, "A Rational Expectations Model of Financial Contagion", Journal of Finance, v57(2), pp769-799. 
Lessard, D., 1973, "International Portfolio Diversification: A Multivariate Analysis for a Group of Latin American Countries", Journal of Finance, v28(3), pp619-633.

Lucas, R., 1988, "On the Mechanics of Economic Development", Journal of Monetary Economics, v22, pp3-42.

Moser, T., 2003, “What Is International Financial Contagion?”, International Finance, v6(2), pp. $157-178$.

Mun, C., 2005, "Contagion and Impulse Response of International Stock Markets around the 9-11 Terrorist Attacks", Global Finance Journal, v16(1), pp. 48-68.

Newey, W. and K. West, 1987, "A Simple, Positive Semi-definite, Heteroskedasticity and Autocorrelation Consistent Covariance Matrix", Econometrica, v55(3), pp703-708.

Phylaktis, K. and F. Ravazzolo, 2002, "Measuring Financial and Economic Integration with Equity Prices in Emerging Markets", Journal of International Money and Finance, v21, pp879-903.

Ramiah, V., M-A Cam, M. Calabro, D. Maher and S. Ghafouri, 2010, "Changes in equity returns and volatility across different Australian industries following the recent terrorist attacks", Pacific-Basin Finance Journal, v18, pp64-76.

Rigobon, R., 2003, "On the Measurement of the International Propogation of Shocks: Is the Transmission Stable?", Journal of International Economics, v61, pp261-283.

Romer, P., 1986, "Increasing Returns and Long-Run Growth", Journal of Political Economy, v94(5), pp1002-1037.

Solnik, B., C. Boucrelle and Y. Le Fur, 1996, "International Market Correlation and Volatility", Financial Analysts Journal, v10, pp17-34. 


\section{TABLE I: MAJOR TERRORIST ATTACK EVENTS}

Table I presents key information pertaining to each terrorist attack comprising our final event sample. For each terrorist attack we identify the date, location, the developed nation of intent that the attack is directed towards; the number of deaths resulting from the attack; and, the number of injuries resulting from the attack. This information is available on the US Department of State's website: http://www.state.gov/issuesandpress.

\begin{tabular}{lccccc}
\hline Terrorist Attack & Date & Location & Nation of Intent & Deaths & Injuries \\
\hline US Embassy bombings & $7^{\text {th }}$ August, 1998 & East Africa & USA & 301 & 5,096 \\
USS Cole attack & $12^{\text {th }}$ October, 2000 & Yemen & USA & 17 & 39 \\
September 11 attacks & $11^{\text {th }}$ September, 2001 & USA & USA & 3,025 & $>5000$ \\
Bali bombings & 12th October, 2002 & Indonesia & Australia & 202 & 400 \\
Madrid bombings & 11th March, 2004 & Spain & Spain & 191 & $>2000$ \\
London bombings & 7th July, 2005 & UK & UK & 56 & 770 \\
\hline Total & & & & $\mathbf{3 , 7 9 2}$ & $>\mathbf{1 3 . 3 0 0}$ \\
\hline
\end{tabular}




\section{TABLE II - PANEL A: DEVELOPED MARKET SAMPLE}

Table II, Panel A presents descriptive statistics for the 21 developed markets daily return series over the 1st January 1996 to the 31 st December 2006 period. Columns (2), (3) and (4) contain for each market the mean market capitalisation $(M V)$ in millions of US dollars, the mean capitalisation relative to the developed market sample $(\% D S M)$ and the full sample of 45 countries $(\% F S)$. Columns (5) through (8) contain descriptive statistics for the returns. MEAN is the average return over the sample, $S D$ is the standard deviation, $S K E W$ and $K U R T$ are the excess skewness and kurtosis, respectively. The final two columns contain test staistics for the normality test (JB) of Jarque and Bera (1980) and the Augmented Dickey Fuller (ADF) test as per Dickey and Fuller (1979). Under the joint null of zero skewness and kurtosis, the JB statistic is distributed as a $\chi_{2}^{2}$. The ADF test has finite-sample critical values against the null of non-stationarity as per MacKinnon (1991). * (**) denotes significance at the 5\% (1\%) level.

\begin{tabular}{|c|c|c|c|c|c|c|c|c|c|}
\hline $\begin{array}{c}\text { Market } \\
\text { (1) }\end{array}$ & $\begin{array}{c}M V \\
(2)\end{array}$ & $\begin{array}{c}\text { \%DSM } \\
\text { (3) }\end{array}$ & $\begin{array}{c}\% F S \\
(4)\end{array}$ & $\begin{array}{c}\text { Mean } \\
(5)\end{array}$ & $\begin{array}{l}S D \\
(6)\end{array}$ & $\begin{array}{c}S K E W \\
\text { (7) }\end{array}$ & $\begin{array}{c}\text { KURT } \\
(8)\end{array}$ & $\begin{array}{l}J B \\
(9)\end{array}$ & $\begin{array}{c}A D F \\
(10)\end{array}$ \\
\hline Australia & 336,157 & $1.57 \%$ & $1.49 \%$ & 0.0004 & 0.0110 & -0.0771 & 5.5100 & $755.7020 * *$ & $-53.8274 * *$ \\
\hline Austria & 22,704 & $0.11 \%$ & $0.10 \%$ & 0.0005 & 0.0109 & -0.3817 & 5.4615 & $793.7290 * *$ & $-50.4304 * *$ \\
\hline Belgium & 128,263 & $0.60 \%$ & $0.57 \%$ & 0.0004 & 0.0119 & 0.2350 & 7.7936 & $2772.3830 * *$ & $-47.3547 * *$ \\
\hline Canada & 537,518 & $2.51 \%$ & $2.39 \%$ & 0.0005 & 0.0120 & -0.4340 & 7.6161 & $2636.3770 * *$ & $-51.2977 * *$ \\
\hline Denmark & 82,779 & $0.39 \%$ & $0.37 \%$ & 0.0006 & 0.0120 & -0.2175 & 5.1225 & $560.9529 * *$ & $-55.1395 * *$ \\
\hline Finland & 120,109 & $0.56 \%$ & $0.53 \%$ & 0.0009 & 0.0232 & -0.1592 & 9.1314 & $4504.8580 * *$ & $-52.7725 * *$ \\
\hline France & $1,022,096$ & $4.77 \%$ & $4.54 \%$ & 0.0005 & 0.0128 & -0.0892 & 5.2487 & $608.0963 * *$ & $-52.1440 * *$ \\
\hline Germany & 745,078 & $3.48 \%$ & $3.31 \%$ & 0.0004 & 0.0145 & -0.0916 & 5.4071 & $696.4225 * *$ & $-53.6806^{* *}$ \\
\hline Hong Kong & 417,954 & $1.95 \%$ & $1.86 \%$ & 0.0003 & 0.0162 & 0.4215 & 15.2790 & $18102.5000^{* *}$ & $-29.1266 * *$ \\
\hline Ireland & 70,090 & $0.33 \%$ & $0.31 \%$ & 0.0004 & 0.0119 & -0.3450 & 6.8810 & $1856.7650 * *$ & $-49.8998 * *$ \\
\hline Italy & 509,636 & $2.38 \%$ & $2.26 \%$ & 0.0004 & 0.0127 & -0.0559 & 5.3689 & $672.0656^{* *}$ & $-52.5169 * *$ \\
\hline Japan & $2,481,586$ & $11.58 \%$ & $11.02 \%$ & 0.0001 & 0.0143 & 0.3751 & 7.4808 & $2466.5640 * *$ & $-52.7366 * *$ \\
\hline Netherlands & 509,775 & $2.38 \%$ & $2.26 \%$ & 0.0003 & 0.0132 & -0.0725 & 6.3120 & $1313.3230 * *$ & $-52.7719 * *$ \\
\hline New Zealand & 18,851 & $0.09 \%$ & $0.08 \%$ & 0.0002 & 0.0133 & -0.2695 & 10.4096 & $6595.5990 * *$ & $-53.1949 * *$ \\
\hline Norway & 63,287 & $0.30 \%$ & $0.28 \%$ & 0.0005 & 0.0136 & -0.2442 & 6.1501 & $1214.3330 * *$ & $-51.9282 * *$ \\
\hline Portugal & 47,285 & $0.22 \%$ & $0.21 \%$ & 0.0004 & 0.0109 & -0.0958 & 5.5039 & $753.5820 * *$ & $-46.9116^{* *}$ \\
\hline Spain & 323,097 & $1.51 \%$ & $1.43 \%$ & 0.0006 & 0.0134 & 0.0103 & 5.4816 & $735.9752 * *$ & $-50.9917 * *$ \\
\hline Sweden & 189,861 & $0.89 \%$ & $0.84 \%$ & 0.0006 & 0.0172 & 0.1281 & 6.48 .53 & $1459.4630 * *$ & $-51.7549 * *$ \\
\hline Switzerland & 566,203 & $2.64 \%$ & $2.51 \%$ & 0.0004 & 0.0121 & 0.0963 & 6.1586 & $1196.6640 * *$ & $-54.4619 * *$ \\
\hline UK & $2,073,950$ & $9.68 \%$ & $9.21 \%$ & 0.0002 & 0.0125 & -0.1183 & 5.1732 & $571.0439 * *$ & $-52.7361 * *$ \\
\hline US & $11,162,540$ & $52.09 \%$ & $49.55 \%$ & 0.0003 & 0.0110 & -0.0137 & 6.3146 & $1312.9560 * *$ & $-54.2468 * *$ \\
\hline
\end{tabular}




\section{TABLE II - PANEL B: EMERGING MARKET SAMPLE}

Table II, Panel B presents descriptive statistics for the 24 emerging markets daily return series over the 1 st January 1996 to the 31 st December 2006 period. Columns (2), (3) and (4) contain for each market the mean market capitalisation ( $M V)$ in millions of US dollars, the mean capitalisation relative to the emerging market sample (\%ESM) and the total sample of 45 countries (\%FS). Columns (5) through (8) contain descriptive statistics for the returns. MEAN is the average return over the sample, $S D$ is the standard deviation, $S K E W$ and $K U R T$ are the excess skewness and kurtosis, respectively. The final two columns contain test staistics for the normality test (JB) of Jarque and Bera (1980) and the Augmented Dickey Fuller (ADF) test as per Dickey and Fuller (1979). Under the joint null of zero skewness and kurtosis, the JB statistic is distributed as a $\chi_{2}^{2}$. The ADF test has finite-sample critical values against the null of non-stationarity as per MacKinnon (1991). * (**) denotes significance at the 5\% (1\%) level.

\begin{tabular}{|c|c|c|c|c|c|c|c|c|c|}
\hline $\begin{array}{c}\text { Market } \\
\text { (1) }\end{array}$ & $\begin{array}{c}M V \\
(2)\end{array}$ & $\begin{array}{c}\text { \%ESM } \\
\text { (3) }\end{array}$ & $\begin{array}{c}\% F S \\
(4)\end{array}$ & $\begin{array}{c}\text { Mean } \\
(5)\end{array}$ & $\begin{array}{l}S D \\
(6)\end{array}$ & $\begin{array}{c}\text { SKEW } \\
\text { (7) }\end{array}$ & $\begin{array}{c}\text { KURT } \\
(8)\end{array}$ & $\begin{array}{l}J B \\
(9)\end{array}$ & $\begin{array}{c}A D F \\
(10)\end{array}$ \\
\hline Argentina & 20,817 & $1.90 \%$ & $0.09 \%$ & 0.0005 & 0.0213 & -1.0654 & 23.0597 & $48628.1300^{* *}$ & $-48.3662 * *$ \\
\hline Brazil & 138,553 & $12.62 \%$ & $0.62 \%$ & 0.0007 & 0.0215 & -0.0933 & 8.5462 & $3679.9890 * *$ & $-37.6669 * *$ \\
\hline Chile & 50,329 & $4.58 \%$ & $0.22 \%$ & 0.0003 & 0.0103 & -0.1162 & 6.3958 & $1384.4610 * *$ & $-42.2125^{* *}$ \\
\hline China & 17,217 & $1.57 \%$ & $0.08 \%$ & 0.0007 & 0.0147 & -0.1510 & 8.6202 & $3785.4760 * *$ & $-51.9052 * *$ \\
\hline Colombia & 3,631 & $0.33 \%$ & $0.02 \%$ & 0.0005 & 0.0141 & 0.1939 & 20.6095 & $37074.30 * *$ & $-41.2569 * *$ \\
\hline Czech Republic & 2,147 & $0.20 \%$ & $0.01 \%$ & 0.0006 & 0.0142 & -0.1633 & 5.2637 & $625.0901 * *$ & $-47.8593 * *$ \\
\hline Egypt & 4,416 & $0.40 \%$ & $0.02 \%$ & 0.0006 & 0.0145 & 0.0662 & 9.3584 & $4833.3640 * *$ & $-33.6798 * *$ \\
\hline Hungary & 5,850 & $0.53 \%$ & $0.03 \%$ & 0.0010 & 0.0191 & -0.3684 & 10.1416 & $6159.6160 * *$ & $-49.1994 * *$ \\
\hline India & 83,490 & $7.60 \%$ & $0.37 \%$ & 0.0006 & 0.0157 & -0.2106 & 7.0397 & $1971.2970 * *$ & $-49.4042 * *$ \\
\hline Indonesia & 24,958 & $2.27 \%$ & $0.11 \%$ & 0.0004 & 0.0310 & 0.0860 & 23.6918 & $51167.6200 * *$ & $-24.1085^{* *}$ \\
\hline Israel & 23,604 & $2.15 \%$ & $0.10 \%$ & 0.0004 & 0.0153 & -0.1597 & 7.5590 & $2495.9880 * *$ & $-51.1425 * *$ \\
\hline Jordan & 3,293 & $0.30 \%$ & $0.01 \%$ & 0.0006 & 0.0112 & 0.2706 & 14.7188 & $16445.8400 * *$ & $-51.7244 * *$ \\
\hline Korea & 157,923 & $14.38 \%$ & $0.70 \%$ & 0.0005 & 0.0261 & 0.7871 & 16.8149 & $23102.6700^{* *}$ & $-27.6538 * *$ \\
\hline Malaysia & 90,067 & $8.20 \%$ & $0.40 \%$ & 0.0001 & 0.0188 & 1.7320 & 39.3135 & $159015.1000 * *$ & $-22.2467 * *$ \\
\hline Mexico & 112,751 & $10.27 \%$ & $0.50 \%$ & 0.0007 & 0.0163 & 0.0814 & 9.8655 & $5635.8340 * *$ & $-37.3635 * *$ \\
\hline Morocco & 5,474 & $0.50 \%$ & $0.02 \%$ & 0.0004 & 0.0087 & 0.2530 & 7.6142 & $2574.8310^{* *}$ & $-44.0104 * *$ \\
\hline Peru & 4,609 & $0.42 \%$ & $0.02 \%$ & 0.0006 & 0.0119 & -0.2454 & 7.9350 & $2939.1150 * *$ & $-47.4551 * *$ \\
\hline Philippines & 18,761 & $1.71 \%$ & $0.08 \%$ & 0.0001 & 0.0181 & 1.4528 & 23.6834 & $52131.1900 * *$ & $-44.5492 * *$ \\
\hline Russia & 30,926 & $2.82 \%$ & $0.14 \%$ & 0.0016 & 0.0306 & -0.0290 & 11.7219 & $9090.8930 * *$ & $-48.9293 * *$ \\
\hline South Africa & 90,381 & $8.23 \%$ & $0.40 \%$ & 0.0003 & 0.0160 & -0.4249 & 7.1000 & $2095.1190 * *$ & $-50.4662 * *$ \\
\hline Sri Lanka & 401 & $0.04 \%$ & $0.00 \%$ & 0.0004 & 0.0151 & 1.9561 & 70.8599 & $552122.6000^{* *}$ & $-36.4904 * *$ \\
\hline Taiwan & 178,185 & $16.22 \%$ & $0.79 \%$ & 0.0002 & 0.0174 & 0.0774 & 5.3719 & $675.1432 * *$ & $-51.7938 * *$ \\
\hline Thailand & 27,479 & $2.50 \%$ & $0.12 \%$ & -0.0001 & 0.0232 & 1.0065 & 13.0445 & $12540.8200 * *$ & $-44.9001 * *$ \\
\hline Venezuela & 3,002 & $0.01 \%$ & $0.01 \%$ & 0.0006 & 0.0258 & -0.3126 & 26.7293 & $67334.45^{* *}$ & $-51.4513 * *$ \\
\hline
\end{tabular}




\section{TABLE III: CONTAGION EFFECTS}

Table III reports the change in cross-market correlation surrounding each of 6 terrorist events. Two contagion measures are used to calculate the return correlations. Panel A uses the raw return contagion definition as per King and Wadwani (1991), while Panel B uses the residuals from fitting the Bekaert, Harvey and $\mathrm{Ng}$ (2005) model. Specifically, the table shows the change in correlations, calculated as the correlation in the 1-month following the terrorist event less the correlation 1-month prior to the event. Columns (4), (5) and (6) report the value-weighted average correlations aggregated over the total sample of 45 countries (column 4), the developed markets sample (column 5) and the emerging markets sample (Column 6), respectively. The final row of each panel contains the average of these figures across all 6 events. $*(* *)$ denotes significance at the $5 \%(1 \%)$ level.

\begin{tabular}{|c|c|c|c|c|c|}
\hline $\begin{array}{c}\text { Contagion } \\
\text { metric } \\
(1) \\
\end{array}$ & $\begin{array}{c}\text { Event } \\
(2) \\
\end{array}$ & $\begin{array}{c}\text { Date } \\
\text { (3) }\end{array}$ & $\begin{array}{c}\text { Full } \\
\text { Sample } \\
\text { (4) } \\
\end{array}$ & $\begin{array}{l}\text { Developed } \\
\text { markets } \\
(5) \\
\end{array}$ & $\begin{array}{c}\text { Emerging } \\
\text { markets } \\
(6) \\
\end{array}$ \\
\hline \multicolumn{6}{|c|}{ PANEL A: Return Correlations } \\
\hline & US Embassy & $7^{\text {th }}$ August, 1998 & $0.0776 * *$ & $0.0993 * *$ & $-0.1252 * *$ \\
\hline & USS Cole & $12^{\text {th }}$ October, 2000 & $0.2228 * *$ & $0.2388 * *$ & 0.0732 \\
\hline & $9 / 11$ & $11^{\text {th }}$ September, 2001 & $0.1988 * *$ & $0.2002 * *$ & $0.1855^{* *}$ \\
\hline & Bali & 12th October, 2002 & $0.1817^{* *}$ & $0.1957 * *$ & -0.0877 \\
\hline & Madrid & 11th March, 2004 & $0.1448^{*}$ & $0.1562 *$ & -0.0750 \\
\hline & London & 7th July, 2005 & 0.0092 & $0.0199 *$ & $-0.1779 * *$ \\
\hline & Average & & $0.1392 * *$ & $0.1517 * *$ & $-0.0345^{* *}$ \\
\hline \multicolumn{6}{|c|}{ PANEL B: Residual Factor } \\
\hline & US Embassy & $7^{\text {th }}$ August, 1998 & $0.0776^{* *}$ & $0.0993 * *$ & $-0.1252 * *$ \\
\hline & USS Cole & $12^{\text {th }}$ October, 2000 & -0.0657 & -0.0657 & -0.0658 \\
\hline & $9 / 11$ & $11^{\text {th }}$ September, 2001 & 0.0090 & 0.0039 & 0.0559 \\
\hline & Bali & 12th October, 2002 & -0.0046 & 0.0063 & $-0.2147 *$ \\
\hline & Madrid & 11th March, 2004 & $0.1112^{* *}$ & $0.1179 *$ & -0.0183 \\
\hline & London & 7th July, 2005 & 0.0718 & 0.0882 & $-0.2182 * *$ \\
\hline & Average & & $0.0332 * *$ & $0.0417 * *$ & $-0.0977 * *$ \\
\hline
\end{tabular}




\section{TABLE IV: THE INTEGRATION EFFECTS OF 9/11}

Table IV reports the integration effects associated with the September 11, 2001 (9/11) terrorist event. Specifically, the table reports changes in various integration metrics calculated across the pre and post event window. Panel A shows the raw return correlations as per King and Wadwhani (1990). The correlations are calculated using each of a 1, 3 and 5 year symmetrical window pre and post the 9/11 event. Panel B reports the change in risk exposures associated with the 9/11 event. Columns (4), (5) and (6) report the value-weighted average of each metric aggregated over the total sample of 45 countries (column 3), the developed markets sample (column 4$)$ and the emerging markets sample (Column 5), respectively. * $(* *)$ denotes significance at the $5 \%(1 \%)$ level.

\begin{tabular}{|c|c|c|c|c|}
\hline $\begin{array}{c}\text { Integration metric } \\
(1)\end{array}$ & $\begin{array}{l}\text { Window } \\
\text { (2) }\end{array}$ & $\begin{array}{c}\text { Full Sample } \\
\text { (3) }\end{array}$ & $\begin{array}{l}\text { Developed } \\
\text { markets } \\
(4)\end{array}$ & $\begin{array}{l}\text { Emerging } \\
\text { markets } \\
\text { (5) }\end{array}$ \\
\hline \multicolumn{5}{|c|}{ PANEL A: Return correlations } \\
\hline & -1 year, + 1 year & 0.0151 & 0.0183 & -0.0154 \\
\hline & -3 years, +3 years & $0.0937 * *$ & $0.1043 * *$ & -0.0046 \\
\hline & -5 years, +5 years & $0.0786^{* *}$ & $0.0868 * *$ & 0.0021 \\
\hline \multicolumn{5}{|c|}{ PANEL B: Change in risk exposures } \\
\hline World Beta & -5 years, +5 years & 0.0331 & 0.0247 & 0.0114 \\
\hline Regional Beta & -5 years, +5 years & $-0.0311 * *$ & $-0.0308 * *$ & -0.0379 \\
\hline Residual Risk Correlation & -5 years, +5 years & -0.0215 & -0.0172 & $-0.0619 *$ \\
\hline
\end{tabular}




\section{FIGURE I: CORRELATIONS AROUND MAJOR TERRORIST EVENTS}

Figure I presents rolling 12-month correlations of the markets in the sample with the MSCI World Index returns over the 1st January 1994 to the 31st December 2006 period. Specifically, the figure illustrates the equally-weighted average of the rolling correlations aggregated for each of the 21 developed markets, 24 emerging markets and the combined 45 markets, respectively.

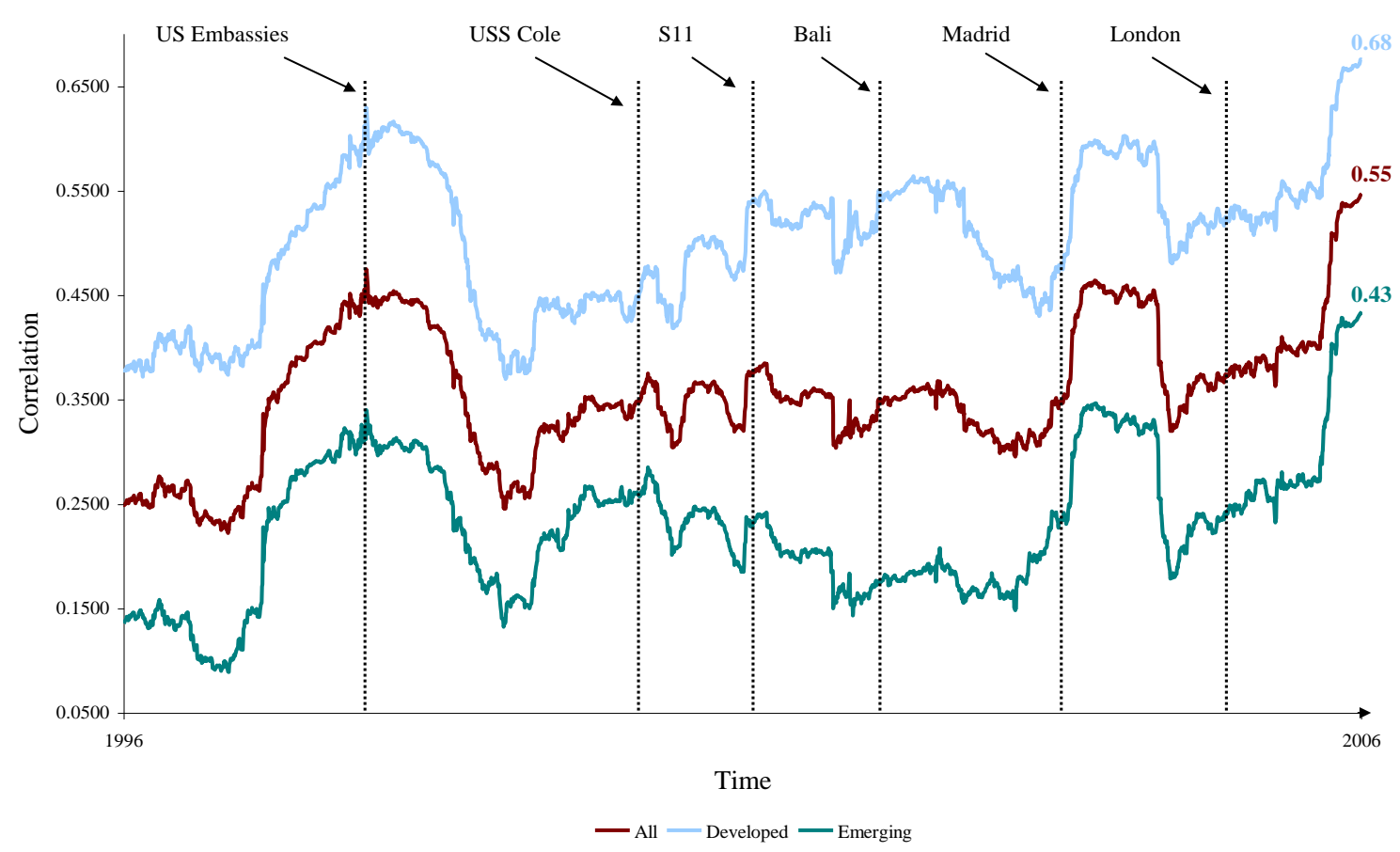

